\title{
Sensory and objective mutton quality characteristics of SA Merino sheep selected for and against reproductive fitness
}

\author{
L.C. Hoffman ${ }^{1 *}$, D. Schmidt ${ }^{1}$, M.M. Muller ${ }^{1}$, J.J.E. Cloete ${ }^{1}$ and S.W.P. Cloete ${ }^{1,2}$ \\ ${ }^{1}$ University of Stellenbosch, Private Bag XI, Matieland 7602, South Africa \\ ${ }^{2}$ Elsenburg Agricultural Centre, Private Bag XI, Elsenburg 7607, South Africa
}

\begin{abstract}
The effect of divergent selection for ewe multiple-rearing ability over a 15 -year period on mutton quality was examined on the M. longissimus dorsi and M. semimembranosus of entire rams (R) and ewes (E) derived from two Merino lines. The selection of these two lines was based on maternal ranking values for multiple-rearing ability in a positive $(\mathrm{P})$ and negative $(\mathrm{N})$ line. In the negative line the replacements were based on the progeny of ewes that rear less than one lamb per joining or lambing opportunity (i.e. failed to lamb or lost all progeny born at least once). Progeny of ewes that reared more than one lamb per joining (i.e. reared twins at least once) were selected for the positive line. Ratings of sensory quality characteristics on the M. semimembranosus of the different genotype lines were obtained from a trained taste panel and related to data on physical and chemical characteristics. The moisture, total lipids, protein, ash, mineral concentrations and fatty acid composition of the M. semimembranosus were obtained. Physical parameters measured on the $M$. longissimus dorsi were: ultimate $\mathrm{pH}\left(\mathrm{pH}_{48}\right)$, drip loss, cooking loss and Warner-Bratzler shear force (WBS). The influence of selection line on the sensory characteristics of the mutton was generally negligible, with the exception of the sensory attribute of first bite, where meat derived from the positive line was rated to be less tender than that of the negative line contemporaries. Chemically, the meat derived from the four different groups differed significantly in moisture and lipid content. The Positive Ram (PR) group had the highest moisture ( $c a .76 \%)$ and the lowest lipid (ca. 7\%) concentrations, whereas the Negative Ewe (NE) group had the lowest moisture (ca. 70\%) and the highest lipid (ca. 10\%) concentration. No significant differences were detected in the proximate chemical composition between the $\mathrm{P}$ and $\mathrm{N}$ lines. The $\mathrm{pH}_{48}$ and WBS values showed significant differences between the four groups. The Negative Ram (NR) group had the highest $\mathrm{pH}_{48}$ and the lowest WBS values. Results indicated a line effect on WBS tenderness. Meat derived from the positive line was less tender compared to the meat from the negative line. Differences between the reproductive lines pertaining to the mineral and fatty acid composition were also noted. A general tendency found, was for the Positive Ewes (PE) to have the highest and the NE to have the lowest mineral concentration. Significant differences were detected between the four groups in the individual fatty acids arachidic acid (C20:0), lignoceric acid (C24:0), eicosenoic acid (C20:1n-9), linoleic acid (C18:2n-6), homo$\gamma$-linolenic acid (C20:3n-6), arachidonic acid (C20:4n-6), eicosapentaenoic acid (C20:5n-3), docosadienoic acid (C22:2n-6), docosapentaenoic acid (C22:5n-3) and docosahexaenoic acid (C22:6n-3) concentrations. The PR group had the highest total PUFA (polyunsaturated fatty acids) content ( $c a .8 \%$ ) and the NR the lowest PUFA content ( $c a .6 \%$ ). The positive group had significantly higher C18:2n-6, C20:3n-6, C20:4n-6, $\mathrm{C} 20: 5 n-3, \mathrm{C} 22: 5 n-3$ and $\mathrm{C} 22: 6 n-3$ concentrations in comparison with the negative line. Significant difference in the total PUFA composition was also detected between lines, with the positive line showing a higher concentration ( $c a .7 \%$ ) compared to the negative line ( $c a .6 \%)$.
\end{abstract}

Keywords: Merino, meat quality, mutton, chemical composition, sensory attributes

${ }^{\#}$ Corresponding author. E-mail: 1ch@sun.ac.za

\section{Introduction}

South African sheep farmers are faced with ever increasing input costs and low product price increases, resulting in the profit margins becoming smaller and smaller. Local farmers need to run their enterprises in the most effective manner in order to survive economically. Given the increasing economic pressures on sheep farmers, it is evident that reproduction should receive the necessary attention. Lamb mortality is regarded as a major constraint on efficient sheep production (Alexander, 1988). It is one of the components of net production rate that is of great importance in small stock farming (Olivier, 1999). The efficiency of reproduction affects all users of animal products such as wool and meat because consumer prices start with production costs (Laas, 1995). The profitability of sheep production in South Africa is 
largely influenced by net reproduction rate, defined as total weight of lamb weaned per ewe joined (Olivier, 1999). Against this background Cloete (1999) undertook an investigation on the divergent selection of South African Merino sheep for multiple-rearing ability. The experiment demonstrated that selection of sheep for multiple-rearing ability was a viable method for improving lamb production without serious negative correlated responses on qualitative and quantitative production traits in progeny (Cloete \& Olivier, 1998). When retained for breeding purposes, the lower producing negative line had a higher average live weight as well as a higher average wool weight when joined at 5.5 years of age than the positive line contemporaries. Stress placed on the positive line ewes by pregnancy and lactation possibly played a role in this regard (Cloete, 1999). However, despite the apparent importance of reproductiveness on aspects such as live weight and fleece weight, little is known about the consequences of reproductive fitness on the quality of mutton in progeny.

The pre-eminent question in this investigation is to what extent does reproduction fitness influence mutton quality. This investigation reports on the differences in sensory attributes, proximate chemical composition, fatty acid and mineral composition between the two lines of South African Merino sheep. Muscle $\mathrm{pH}$, cooking loss and drip loss and Warner-Bratzler shear force (WBS) were also determined.

\section{Materials and methods}

Since 1986 two lines of South African Merino sheep have been divergently selected for and against multiple-rearing ability from the same base population at the Tygerhoek Experimental Farm. Selection of ewe and ram replacements were based on maternal ranking values for multiple-rearing ability in a positive (P) and negative (N) line (Cloete \& Durand, 1994; Cloete \& Scholtz, 1998). In the negative line progeny of ewes that rear less than one lamb per joining or lambing opportunity (i.e. failed to lamb or lost all progeny born at least once) were preferred as replacements. Progeny of ewes that reared more than one lamb per joining (i.e. reared twins at least once) were preferably selected as replacements in the positive line. At the end of 1992 both lines were transferred to Elsenburg experimental farm for detailed data collection on lamb mortality, lambing and neonatal behaviour, lamb production, weight and wool traits (Cloete \& Scholtz, 1998).

In this investigation 10 mature animals (equal sex ratio) from the positive and 10 from the negative reproduction lines (of the 5th generation) were randomly selected to test for the effect of reproductiveness and sex on the physico-chemical and sensory characteristics of the mutton. The animals from both lines originated from similar environments, although the rams and ewes were kept apart to avoid casual mating. The animals grazed on adjacent wheat stubble fields that were rotated regularly. The sheep were grown to commercial slaughter weight and slaughtered, using standard South African techniques and conditions. The mean live weights for the positive line were $44.7 \mathrm{~kg}(\mathrm{n}=10)$ and for the negative line $42.0 \mathrm{~kg}(\mathrm{n}=10)$. No electrical stimulation was applied. During the first $48 \mathrm{~h}$ post-mortem, the carcasses were chilled at a temperature of $5{ }^{\circ} \mathrm{C}$. Ultimate $\mathrm{pH}$ was measured $48 \mathrm{~h}$ post-mortem $\left(\mathrm{pH}_{48}\right)$ with a penetrating glass electrode on a hand-held Crison $\mathrm{pH} / \mathrm{mV}-506$ meter. The $\mathrm{pH}$ meter was re-calibrated after every fourth reading and the electrode rinsed with distilled water between each measurement. The $\mathrm{pH}$ meter contained a temperature probe ensuring automatic adjustment of the $\mathrm{pH}$ for temperature. The measurement was taken between the $2^{\text {nd }}$ and $3^{\text {rd }}$ last thoracic vertebrae, $45 \mathrm{~mm}$ from the midline. The $M$. longissimus dorsi was removed from the carcass to assess drip loss, cooking loss, shear force and $\mathrm{pH}_{48}$. The legs were removed from the carcasses at a position between the last lumbar and the first sacral vertebrae. The legs were labelled, vacuum packed, frozen and stored at $-18{ }^{\circ} \mathrm{C}$ until further use. After thawing, the M. semimembranosus from both the legs were dissected and used for sensory, proximate, mineral and fatty acid analyses.

The right legs were defrosted at a temperature of $3-4{ }^{\circ} \mathrm{C}$ for a period of $48 \mathrm{~h}$ for the purpose of deboning and the removal of the $M$. semimembranosus. The legs were placed on a flat surface with the lateral side facing upwards. An incision was made on the septa, followed by an incision of the knife at the top end and cutting as close as possible to the pelvic bone. The natural division between muscles then became visible and the $M$. semimembranosus could then be separated from the other muscles by cutting between the muscles. The $M$. semimembranosus cuts were coded, vacuum packed, re-frozen and stored at $-18{ }^{\circ} \mathrm{C}$ until further analysis. $M$. semimembranosus samples were oven-roasted prior to subsequent sensory analysis. The meat cuts were defrosted for $48 \mathrm{~h}$ at a temperature of $3-4{ }^{\circ} \mathrm{C}$, wrapped individually in cooking bags and placed fat-side up on the rack of an open roasting pan. The samples were roasted at $160{ }^{\circ} \mathrm{C}$ in two conventional electric Defy 835 ovens connected to a computerised electronic temperature control system 
(Viljoen et al., 2001). A thermocouple was inserted in the centre of each sample and the meat was roasted to an internal temperature of $70{ }^{\circ} \mathrm{C}$ (AMSA, 1978). Immediately after cooking all visible subcutaneous fat was removed from each sample. Six $1.5 \mathrm{~cm}$ x $1.5 \mathrm{~cm}$ cubed samples were taken from the middle of each sample and wrapped immediately in aluminium foil marked with random three digit codes. The samples were placed in preheated glass ramekins in a preheated oven of $100{ }^{\circ} \mathrm{C}$ and evaluated within $10 \mathrm{~min}$ by the panellists. Descriptive sensory analyses were performed on the meat samples. Panellists were selected and trained in accordance with the American Meat Science Association guidelines for the sensory evaluation of meat (AMSA, 1978). A six-member panel evaluated the meat for the following sensory attributes: aroma intensity, initial impression of juiciness, sustained juiciness, tenderness, residue and overall lamb flavour by means of an eight-point structured line scale. Table 1 depicts the definitions of the attributes used in the sensory analyses. The panellists were seated in individual booths in a temperature and light controlled room, receiving a set of four samples served in a complete randomised order. Crackers and distilled water were used to cleanse the palate between samples (AMSA, 1978).

Table 1: Definition of attributes for sensory analyses of mutton

\begin{tabular}{|c|c|}
\hline Attribute & Definition \\
\hline $\begin{array}{l}\text { Lamb aroma } \\
1=\text { Extremely bland; } 8=\text { Extremely intense }\end{array}$ & Aroma associated with the animal species \\
\hline $\begin{array}{l}\text { Initial juiciness } \\
1=\text { Extremely dry; } 8=\text { Extremely juicy }\end{array}$ & $\begin{array}{l}\text { The amount of fluid exuded on the cut surface } \\
\text { when pressed between fingers }\end{array}$ \\
\hline $\begin{array}{l}\text { Sustained juiciness } \\
1=\text { Extremely dry; } 8=\text { Extremely juicy }\end{array}$ & $\begin{array}{l}\text { Degree/amount of water perceived during } \\
\text { mastication }\end{array}$ \\
\hline $\begin{array}{l}\text { First bite } \\
1=\text { Extremely tough; } 8=\text { Extremely tender }\end{array}$ & $\begin{array}{l}\text { Force needed to compress the sample of meat } \\
\text { between molar teeth on the first bite }\end{array}$ \\
\hline $\begin{array}{l}\text { Residue } \\
1=\text { Abundant } ; 8=\text { None }\end{array}$ & $\begin{array}{l}\text { The connective tissue remaining after most of the } \\
\text { sample has been masticated }\end{array}$ \\
\hline $\begin{array}{l}\text { Lamb flavour } \\
1=\text { Extremely bland; } 8=\text { Extremely intense }\end{array}$ & Flavour associated with the animal species \\
\hline
\end{tabular}

Proximate chemical analyses were carried out on the raw M. semimembranosus from the left leg (the subcutaneous fat layer was included). Total percentages of moisture, protein and ash were determined according to AOAC methods (AOAC, 1997). The protein concentration was determined by the block digestion method and ashing was done at $500{ }^{\circ} \mathrm{C}$ for $5 \mathrm{~h}$. The moisture content was determined by drying at $100{ }^{\circ} \mathrm{C}$ for $24 \mathrm{~h}$. The lipid content was determined by means of chloroform:methanol extraction (Lee et al., 1996).

For the drip loss determination, $c a .1 .5 \mathrm{~cm}$ thick meat samples from the $M$. longissimus dorsi were weighed immediately after being removed from the carcass. The samples were placed in netting and suspended in an inflated plastic bag. After a storage period of $24 \mathrm{~h}$ at $4{ }^{\circ} \mathrm{C}$, samples were weighed again and the drip loss was calculated as weight loss expressed as a percentage of the original weight of the sample (Honikel, 1998). For the cooking loss determination, the freshly cut M. longissimus dorsi samples (ca. $1.5 \mathrm{~cm}$ thick) were weighed and placed in thin-walled plastic bags in a water-bath at $75{ }^{\circ} \mathrm{C}$. After one hour the samples were removed from the water-bath, cooled in cold water, blotted dry and weighed. Cooking loss was calculated as the difference in sample weight before and after cooking, expressed as a percentage of the initial sample weight (Honikel, 1998). The WBS measurements of the cooked M. longissimus dorsi samples were obtained with a Warner-Bratzler shear attachment (Voisey, 1976) fitted to an Instron Universal Testing Machine (Model 4444). Three cylindrical cores were cut from each muscle using a $12.7 \mathrm{~mm}$ diameter bore. Samples were randomly removed from the centre of each $M$. longissimus dorsi muscle. Maximum WBS values $(\mathrm{N})$ required to shear a cylindrical core of cooked muscle perpendicular to the grain (at a crosshead speed of $200.0 \mathrm{~mm} / \mathrm{min}$ ) were recorded for each sample and the mean was calculated for each muscle. An increasing value indicated greater WBS and, therefore, tougher meat.

A wet ashing method was used to prepare the meat samples for mineral analysis. The elements calcium $(\mathrm{Ca})$, iron $(\mathrm{Fe})$, selenium $(\mathrm{Se})$, potassium $(\mathrm{K})$, magnesium $(\mathrm{Mg})$, sodium $(\mathrm{Na})$, phosphorus $(\mathrm{P})$, zinc $(\mathrm{Zn})$, copper $(\mathrm{Cu})$, and lead $(\mathrm{Pb})$ of the digesta were determined by direct current plasma emission spectrometry (Pinta, 1982). 
After the extraction of the lipids, the fatty acid methyl esters (FAME) were prepared according to procedures published by Morrison \& Smith (1964). The FAME were analysed with a gas-liquid chromatograph (Varian Model 3300), equipped with flame ionisation detection and two $30 \mathrm{~m}$ fused silica megabore DB-225 columns of $0.53 \mathrm{~mm}$ internal diameter (J\&W Scientific, Folsom, CA). Gas flow rates were hydrogen $25 \mathrm{ml} / \mathrm{min}$ and nitrogen (carrier gas) $5-8 \mathrm{ml} / \mathrm{min}$. The temperature programme was linear at 4 ${ }^{\circ} \mathrm{C} / \mathrm{min}$ with initial and final temperatures of $160^{\circ} \mathrm{C}$ and $220^{\circ} \mathrm{C}$ (held for $10 \mathrm{~min}$ ), respectively. The injector temperature was $240{ }^{\circ} \mathrm{C}$ and the detector temperature $250{ }^{\circ} \mathrm{C}$. The FAME were identified by comparison of the retention times to those of a standard FAME mixture (Nu-Chek-Prep Inc., Elysian, Minnesota).

The experiment consisted of a completely randomised design $(2 \times 2$ factorial $)$ with two reproduction lines (P and N) and two sexes (S and D) as the factors. Data were also pooled to test for the main effects of reproduction line and sex. An experimental unit was a carcass from which samples were taken for measurements. Prior to analysis of variance the sensory scores were transformed to ranks. A factorial analysis of variance was performed on all data using SAS version 8.12 (SAS, 1990). The Shapiro-Wilk test was performed to test for non-normality (Shapiro \& Wilk, 1965). In some cases deviations from normality were the cause of one or two outliners, which were excluded before the final analysis. In cases where there was still significant evidence of non-normality, this could be ascribed to kurtosis rather than skewness. Interpretation of the results was thus continued (Glass et al., 1972). Student's t-Least Significant Differences (LSD) were calculated at the $5 \%$ significance level to compare treatment means.

\section{Results and Discussion}

Table 2 Rank means (Means) for the sensory quality characteristics of M. semimembranosus as influenced by the main effects of line and sex

\begin{tabular}{|c|c|c|c|c|c|}
\hline \multirow{2}{*}{$\begin{array}{r}\text { Line } \\
\text { Sex }\end{array}$} & \multicolumn{2}{|c|}{ Positive } & \multicolumn{2}{|c|}{ Negative } & \multirow[b]{2}{*}{$\mathrm{LSD}^{\mathrm{c}}$} \\
\hline & Ewe & Ram & Ewe & Ram & \\
\hline Aroma $^{\mathrm{d}}$ & $\begin{array}{c}2.92 \\
(6.13)\end{array}$ & $\begin{array}{c}2.48 \\
(5.83)\end{array}$ & $\begin{array}{c}2.48 \\
(5.79)\end{array}$ & $\begin{array}{c}2.13 \\
(5.58)\end{array}$ & NS \\
\hline Initial juiciness $^{\mathrm{e}}$ & $\begin{array}{c}2.90 \\
(6.29)\end{array}$ & $\begin{array}{c}2.52 \\
(5.88)\end{array}$ & $\begin{array}{c}2.27 \\
(5.92)\end{array}$ & $\begin{array}{c}2.31 \\
(6.08)\end{array}$ & NS \\
\hline Sustained juiciness ${ }^{\mathrm{f}}$ & $\begin{array}{c}2.98 \\
(6.38)\end{array}$ & $\begin{array}{c}2.38 \\
(5.96)\end{array}$ & $\begin{array}{c}2.35 \\
(6.00)\end{array}$ & $\begin{array}{l}2.29 \\
(5.96)\end{array}$ & NS \\
\hline First bite ${ }^{\mathrm{g}}$ & $\begin{array}{l}3.02^{\mathrm{a}} \\
(6.38)\end{array}$ & $\begin{array}{l}2.33^{\mathrm{ab}} \\
(5.88)\end{array}$ & $\begin{array}{l}2.46^{a b} \\
(6.04)\end{array}$ & $\begin{array}{l}2.19^{b} \\
(5.92)\end{array}$ & 0.83 \\
\hline Residue $^{\text {h }}$ & $\begin{array}{c}2.31 \\
(5.63)\end{array}$ & $\begin{array}{c}2.60 \\
(5.75)\end{array}$ & $\begin{array}{c}2.63 \\
(5.79)\end{array}$ & $\begin{array}{c}2.46 \\
(5.75)\end{array}$ & NS \\
\hline Flavour $^{\mathrm{i}}$ & $\begin{array}{c}2.79 \\
(6.29)\end{array}$ & $\begin{array}{l}2.63 \\
(6.21)\end{array}$ & $\begin{array}{c}2.44 \\
(6.04)\end{array}$ & $\begin{array}{l}2.15 \\
(5.92)\end{array}$ & NS \\
\hline
\end{tabular}

${ }^{\mathrm{a}, \mathrm{b}}$ Rank means in the same row with different superscripts are significantly different $(\mathrm{P} \leq 0.05)$

${ }^{\mathrm{c}}$ Least significant difference $(\mathrm{P}=0.05) ; \mathrm{NS}=$ Not significant $(\mathrm{P}>0.05)$

${ }^{\mathrm{d}}$ Aroma: 1 = extremely bland; $8=$ extremely intense

${ }^{\mathrm{e}}$ Initial juiciness: 1 = extremely dry; $8=$ extremely juicy

${ }^{\mathrm{f}}$ Sustained juiciness: 1 = extremely dry; $8=$ extremely juicy

${ }^{\mathrm{g}}$ First bite: $1=$ extremely tough; $8=$ extremely tender

${ }^{\mathrm{h}}$ Residue: $1=$ abundant; $8=$ none

${ }^{\mathrm{i}}$ Flavour: 1 = extremely bland; $8=$ extremely intense

Rank means for sensory quality characteristics of the M. semimembranosus are presented in Table 2. The means are also provided below the rank means (in brackets) for the interpretation of the results using the rating scale. All sensory quality characteristics, except first bite, were similar $(\mathrm{P}>0.05)$ for all the groups. The first bite of the meat from the four groups differed $(\mathrm{P} \leq 0.05)$, with the PE (Positive line, Ewe) group having the highest (3.0) and the NR (Negative line, Ram) group having the lowest (2.2) rank means. The latter represents the tougher product. The results of this experiment further indicate that, although not significant $(\mathrm{P}>0.05)$, the sensory panel also rated the $\mathrm{PE}$ group higher in initial juiciness, sustained juiciness and flavour, and slightly higher in the perceived amount of residue compared to the other groups. 
When the data were pooled for main effect of line, differences $(\mathrm{P} \leq 0.05)$ were only observed in flavour intensity (Table 3). Meat from the positive line was rated more flavoursome (2.7) than the negative line (2.3). The slightly higher flavour intensity of the positive reproduction line could be the result of differences in the fatty acid profile (Table 11, Fisher et al., 2000).

Table 3 Rank means (Means) for the sensory quality characteristics of M.semimembranosus as influenced by main effects of line and sex

\begin{tabular}{|c|c|c|c|c|c|c|}
\hline & \multicolumn{2}{|c|}{ Line } & \multirow{2}{*}{$\mathrm{LSD}^{\mathrm{c}}$} & \multicolumn{2}{|c|}{ Sex } & \multirow{2}{*}{ LSD } \\
\hline & Positive & Negative & & Ram & Ewe & \\
\hline Aroma $^{\mathrm{d}}$ & $\begin{array}{c}2.70 \\
(5.98)\end{array}$ & $\begin{array}{c}2.30 \\
(5.69)\end{array}$ & NS & $\begin{array}{c}2.30 \\
(5.71)\end{array}$ & $\begin{array}{c}2.70 \\
(5.96)\end{array}$ & NS \\
\hline Initial juiciness $^{\mathrm{e}}$ & $\begin{array}{c}2.60 \\
(6.08)\end{array}$ & $\begin{array}{c}2.40 \\
(6.00)\end{array}$ & NS & $\begin{array}{c}2.42 \\
(5.98)\end{array}$ & $\begin{array}{c}2.58 \\
(6.10)\end{array}$ & NS \\
\hline Sustained juiciness ${ }^{\mathrm{f}}$ & $\begin{array}{c}2.68 \\
(6.17)\end{array}$ & $\begin{array}{c}2.32 \\
(5.98)\end{array}$ & NS & $\begin{array}{c}2.33 \\
(5.96)\end{array}$ & $\begin{array}{c}2.67 \\
(6.19)\end{array}$ & NS \\
\hline First Bite ${ }^{\mathrm{g}}$ & $\begin{array}{c}2.68 \\
(6.13)\end{array}$ & $\begin{array}{c}2.32 \\
(5.98)\end{array}$ & NS & $\begin{array}{c}2.26^{\mathrm{b}} \\
(5.90)\end{array}$ & $\begin{array}{c}2.74^{\mathrm{a}} \\
(6.21)\end{array}$ & 0.44 \\
\hline Residue $^{\mathrm{h}}$ & $\begin{array}{c}2.46 \\
(5.69)\end{array}$ & $\begin{array}{c}2.54 \\
(5.77)\end{array}$ & NS & $\begin{array}{c}2.53 \\
(5.75)\end{array}$ & $\begin{array}{c}2.47 \\
(5.71)\end{array}$ & NS \\
\hline Flavouri & $\begin{array}{l}2.71^{\mathrm{a}} \\
(6.25)\end{array}$ & $\begin{array}{c}2.29^{b} \\
(5.98)\end{array}$ & 0.40 & $\begin{array}{c}2.39 \\
(6.06)\end{array}$ & $\begin{array}{c}2.62 \\
(6.17)\end{array}$ & NS \\
\hline
\end{tabular}

${ }^{\mathrm{a}, \mathrm{b}}$ Rank means in the same row with different superscripts are significantly different $(\mathrm{P} \leq 0.05)$

${ }^{\mathrm{c}}$ Least significant difference $(\mathrm{P}=0.05), \mathrm{NS}=$ Not significant $(\mathrm{P}>0.05)$

${ }^{\mathrm{d}}$ Aroma: 1 = extremely bland; $8=$ extremely intense

${ }^{\mathrm{e}}$ Initial juiciness: 1 = extremely dry; $8=$ extremely juicy

${ }^{\mathrm{f}}$ Sustained juiciness: $1=$ extremely dry; $8=$ extremely juicy

${ }^{\mathrm{g}}$ First bite: 1 = extremely tough; $8=$ extremely tender

${ }^{\text {h }}$ Residue: 1 = abundant; $8=$ none

${ }^{\mathrm{i}}$ Flavour: 1 = extremely bland; $8=$ extremely intense

When pooled for ram and ewe effects (Table 3$)$, differences $(\mathrm{P} \leq 0.05)$ were found in first bite with the ewe group having the highest score (2.74) and the ram group having the lowest taste panel score (2.26). Therefore, meat derived from ewes was more tender than meat from rams. However, Ellis et al. (1997), found no palatability differences between sexes in meat quality. Results of the present investigation agree with findings by Jeremiah et al. (1998), who in a study comparing cooking properties and palatability attributes between 1660 lambs varying in chronicle age, slaughter weight and gender, found that meat derived from ewe lambs was more tender than roasts from rams. In this latter study these differences became more pronounced when secondary sexual characteristics (particularly as pertaining to the rams) had developed.

The moisture, protein, fat and ash contents of the M. semimembranosus samples are presented in Table 4. The meat from the four distinct groups differed $(\mathrm{P} \leq 0.05)$ in moisture and lipid levels. The level of moisture was highest in the PR group (ca. 76\%) and lowest in the NE group (ca. 70\%). The PR group also had the lowest lipid concentration (ca. 7\%) and the NE group the highest (ca. 10\%). No significant differences between the four groups were detected regarding the ash or protein levels.

When pooled for sex (Table 5), the ewes had a significant lower moisture (ca. 71\%) and higher lipid content ( $\mathrm{ca} .10 \%)$ than the rams $(\mathrm{P} \leq 0.05)$. In a study by Ellis et al. (1997) carcasses from female lambs, compared to males showed thicker subcutaneous and greater intermuscular fat content. Observed trends by Jeremiah et al. (1997) further substantiate the fact that rams produce leaner carcasses than ewes. Tendencies in flavour intensity differences between ewes and rams suggested an association between the higher lipid content of the mutton derived from ewes and the flavour, aroma, initial juiciness and sustained juiciness ratings of their meat. The quantity of fat and its quality affect the nutritive value, appearance, processability, shelf life and palatability of meat. Therefore, fat is an important determinant of meat quality, and the degree of saturation of the fat contributes substantially to the sensory properties of meat (Rhee, 1992; Webb et al., 1994). 
Table 4 Means for the proximate chemical analysis of $M$. semimembranosus as influenced by the interaction between the main effects of line and $\mathrm{sex}(\mathrm{g} / 100 \mathrm{~g}$ meat sample)

\begin{tabular}{|c|c|c|c|c|c|c|}
\hline \multirow{2}{*}{\multicolumn{2}{|c|}{$\begin{array}{r}\text { Line } \\
\text { Sex } \\
\end{array}$}} & \multicolumn{2}{|c|}{ Positive } & \multicolumn{2}{|c|}{ Negative } & \multirow[b]{2}{*}{$\mathrm{LSD}^{\mathrm{d}}$} \\
\hline & & Ewe & Ram & Ewe & Ram & \\
\hline Moisture & & $71.67^{b c}$ & $75.94^{\mathrm{a}}$ & $70.04^{c}$ & $73.91^{\mathrm{ab}}$ & 3.16 \\
\hline Protein & & 16.29 & 17.12 & 16.68 & 16.12 & $\mathrm{NS}^{\mathrm{e}}$ \\
\hline Lipid & & $9.29^{\mathrm{ab}}$ & $6.66^{\mathrm{b}}$ & $9.82^{\mathrm{a}}$ & $6.69^{\mathrm{b}}$ & 2.94 \\
\hline Ash & & 1.08 & 1.02 & 1.04 & 1.09 & NS \\
\hline
\end{tabular}

Table 5 Means for the proximate chemical analysis of $M$. semimembranosus as influenced by main effects of line and sex ( $\mathrm{g} / 100 \mathrm{~g}$ meat sample)

\begin{tabular}{lcccccc}
\hline & \multicolumn{2}{c}{ Line } & & \multicolumn{2}{c}{ Sex } & \\
\cline { 2 - 3 } \cline { 5 - 6 } \cline { 5 - 6 } & Positive & Negative & LSD $^{\mathrm{c}}$ & Ram & Ewe & LSD \\
\hline Moisture & 74.04 & 72.46 & $\mathrm{NS}^{\mathrm{d}}$ & $74.93^{\mathrm{a}}$ & $70.97^{\mathrm{b}}$ & 2.223 \\
Protein & 16.75 & 16.32 & $\mathrm{NS}$ & 16.62 & 16.46 & $\mathrm{NS}$ \\
Lipid & 7.83 & 7.86 & $\mathrm{NS}$ & $6.67^{\mathrm{b}}$ & $9.52^{\mathrm{a}}$ & 2.07 \\
Ash & 1.04 & 1.07 & $\mathrm{NS}$ & 1.06 & 1.06 & $\mathrm{NS}$ \\
\hline${ }^{\mathrm{a}, \mathrm{b}}$ Means in the same row with different superscripts are significantly different $(\mathrm{P} \leq 0.05)$ \\
${ }^{\mathrm{c}}$ Least significant difference $(\mathrm{P}=0.05)$ \\
${ }^{\mathrm{d}}$ Not significant $(\mathrm{P}>0.05)$
\end{tabular}

The pooled $\mathrm{P}$ and $\mathrm{N}$ groups did not differ $(\mathrm{P}>0.05)$ in moisture, protein, lipid or ash contents (Table 5). This could possibly be due to the large co-efficient of variation shown by the means. Physical measured traits, $\mathrm{pH}_{48}$, cooking loss, drip loss and WBS resistance of the M. longissimus dorsi, are presented in Table 6 .

Table 6 Means of $\mathrm{pH}_{48}$, drip loss, cooking loss and shear force resistance of lamb $M$. longissimus dorsi as influenced by the main interaction between the effects of line and sex

\begin{tabular}{|c|c|c|c|c|c|c|}
\hline & \multirow{2}{*}{$\begin{array}{l}\text { Line } \\
\text { Sex }\end{array}$} & \multicolumn{2}{|c|}{ Positive } & \multicolumn{2}{|c|}{ Negative } & \multirow[b]{2}{*}{$\operatorname{LSD}^{\mathrm{d}}$} \\
\hline & & Ewe & Ram & Ewe & Ram & \\
\hline $\mathrm{pH}_{48}$ & & $5.624^{\mathrm{b}}$ & $5.716^{\mathrm{b}}$ & $5.588^{\mathrm{b}}$ & $5.874^{\mathrm{a}}$ & 0.129 \\
\hline Drip loss $(\%)$ & & 1.480 & 1.075 & 1.375 & 1.292 & $\mathrm{NS}^{\mathrm{e}}$ \\
\hline Cooking loss $(\%)$ & & 29.92 & 25.74 & 25.63 & 31.53 & NS \\
\hline $\mathrm{WBS}^{\mathrm{f}}(\mathrm{N})$ & & $168.05^{\mathrm{a}}$ & $106.58^{b c}$ & $129.54^{b}$ & $95.34^{\mathrm{c}}$ & 26.39 \\
\hline
\end{tabular}

The $\mathrm{pH}_{48}$ and WBS values showed differences $(\mathrm{P} \leq 0.05)$ between the four groups. The NR group had the highest $\mathrm{pH}_{48}$ and the lowest WBS value. The significant difference in WBS values was, however, not reflected by findings of the taste panel for the attribute of first bite (Table 2). A possible explanation could be that the latter was conducted on the M. semimembranosus and the physical measurements on the $M$. longissimus. The latter muscle is known to be more responsive to temperature, genetics, cooking methods, etc. When ram and ewe groups were pooled (Table 7), differences $(\mathrm{P} \leq 0.05)$ were found for $\mathrm{pH}_{48}, \mathrm{WBS}$ values and cooking loss. Rams had higher ultimate $\mathrm{pH}$ and cooking loss values and a lower WBS value than ewes $(\mathrm{P}<0.05)$. There was a tendency for the higher $\mathrm{pH}_{48}$ values to result in lower WBS values, with the pooled ram group having the highest $\mathrm{pH}_{48}$ value and the lowest WBS value. Results in Table 7 also indicate a 
line effect on meat tenderness. The positive line group had higher $(\mathrm{P} \leq 0.05)$ WBS values, indicating that meat derived from the positive line is less tender compared to the meat from the negative line.

Table 7 Means of $\mathrm{pH}_{48}$, drip loss, cooking loss and shear force resistance of lamb M. longissimus dorsi as influenced by line and sex

\begin{tabular}{|c|c|c|c|c|c|c|}
\hline & \multicolumn{2}{|c|}{ Line } & \multirow[b]{2}{*}{$\operatorname{LSD}^{\mathrm{c}}$} & \multicolumn{2}{|c|}{ Sex } & \multirow[b]{2}{*}{ LSD } \\
\hline & Positive & Negative & & Ram & Ewe & \\
\hline $\mathrm{pH}_{48}$ & 5.67 & 5.73 & $\mathrm{NS}^{\mathrm{d}}$ & $5.80^{\mathrm{a}}$ & $5.61^{b}$ & 0.09 \\
\hline Drip loss $(\%)$ & 1.28 & 1.33 & NS & 1.18 & 1.43 & NS \\
\hline Cooking loss $(\%)$ & 27.83 & 27.47 & NS & 30.72 & 27.77 & NS \\
\hline $\mathrm{WBS}^{\mathrm{e}}(\mathrm{N})$ & $137.3^{\mathrm{a}}$ & $112.4^{\mathrm{b}}$ & 18.66 & $101.0^{\mathrm{b}}$ & $148.8^{\mathrm{a}}$ & 18.66 \\
\hline
\end{tabular}

Conflicting reports regarding the relationship between $\mathrm{pH}$ and tenderness (WBS and sensory tenderness) are found in the literature. Young et al. (1993) showed a curvilinear relationship between $\mathrm{pH}$ and WBS values, while Safari et al. (2001) found no relationship between pH and WBS or tenderness in four lamb genotypes. No significant correlations were found in this investigation.

Results from this study indicated differences $(\mathrm{P} \leq 0.05)$ between the four groups involved in the line $\mathrm{x}$ sex interaction regarding the $\mathrm{Ca}, \mathrm{Fe}, \mathrm{K}, \mathrm{Mg}, \mathrm{P}$ and $\mathrm{Zn}$ concentrations (Table 8). The major contributors to the mineral concentration of the mutton were $\mathrm{K}( \pm 122 \mathrm{mg} / 100 \mathrm{~g}$ meat sample) and $\mathrm{P}(c a .110 \mathrm{mg} / 100 \mathrm{~g}$ meat sample). There was a general tendency for the PE group to have the highest mineral concentration, except for $\mathrm{Zn}$ and $\mathrm{Cu}$, whereas the $\mathrm{NE}$ group had the lowest concentration in all the minerals, except for Se.

Table 8 Means for mineral composition of M. semimembranosus as influenced by the interactions between the main effects of line and sex (mg/100 g meat sample)

\begin{tabular}{|c|c|c|c|c|c|c|}
\hline \multirow{2}{*}{\multicolumn{2}{|c|}{$\begin{array}{l}\text { Line } \\
\text { Sex }\end{array}$}} & \multicolumn{2}{|c|}{ Positive } & \multicolumn{2}{|c|}{ Negative } & \multirow[b]{2}{*}{$\operatorname{LSD}^{\mathrm{c}}$} \\
\hline & & Ewe & Ram & Ewe & Ram & \\
\hline $\mathrm{Ca}$ & & $6.498^{\mathrm{a}}$ & $5.792^{\mathrm{a}}$ & $3.347^{b}$ & $4.622^{\mathrm{ab}}$ & 2.420 \\
\hline $\mathrm{Fe}$ & & $1.828^{\mathrm{a}}$ & $1.747^{\mathrm{a}}$ & $1.108^{\mathrm{b}}$ & $1.335^{\mathrm{ab}}$ & 0.575 \\
\hline $\mathrm{Se}$ & & 0.087 & 0.054 & 0.067 & 0.054 & NS \\
\hline K & & $134.5^{\mathrm{a}}$ & $128.1^{\mathrm{ab}}$ & $99.63^{\mathrm{b}}$ & $126.9^{\mathrm{ab}}$ & 28.73 \\
\hline $\mathrm{Mg}$ & & $19.15^{\mathrm{a}}$ & $18.13^{\mathrm{ab}}$ & $14.93^{\mathrm{b}}$ & $16.57^{\mathrm{ab}}$ & 3.998 \\
\hline $\mathrm{Na}$ & & 17.56 & 17.76 & 13.36 & 17.29 & NS \\
\hline $\mathrm{P}$ & & $124.1^{\mathrm{a}}$ & $117.1^{\mathrm{a}}$ & $92.02^{\mathrm{b}}$ & $107.7^{\mathrm{ab}}$ & 24.49 \\
\hline $\mathrm{Zn}$ & & $2.717^{\mathrm{a}}$ & $2.966^{\mathrm{a}}$ & $2.077^{\mathrm{b}}$ & $2.403^{\mathrm{ab}}$ & 0.583 \\
\hline $\mathrm{Cu}$ & & 0.003 & 0.012 & $\operatorname{tr}^{\mathrm{e}}$ & 0.028 & NS \\
\hline $\mathrm{Pb}$ & & 0.007 & 0.001 & $\operatorname{tr}$ & 0.003 & NS \\
\hline
\end{tabular}

${ }^{\mathrm{a}, \mathrm{b}}$ Means in the same row with different superscripts are significantly different $(\mathrm{P} \leq 0.05)$

${ }^{\mathrm{c}}$ Least significant difference $(\mathrm{P}=0.05)$

${ }^{\mathrm{d}} \mathrm{NS}=$ Not significant $(\mathrm{P}>0.05)$

${ }^{\mathrm{e}}$ trace $=<0.001 \mathrm{mg} / 100 \mathrm{~g}$ meat sample

When pooled together across sexes for positive and negative reproduction groups (Table 9), positive line animals had higher concentrations of $\mathrm{Ca}, \mathrm{Fe}, \mathrm{P}$ and $\mathrm{Zn}$ than their negative line contemporaries. Rams and ewes did not differ with regard to mineral concentrations. 
Table 9 Means for mineral composition of $M$. semimembranosus as influenced by the main effects of line and sex (mg/100 g meat sample)

\begin{tabular}{|c|c|c|c|c|c|c|}
\hline & \multicolumn{2}{|c|}{ Line } & \multirow[b]{2}{*}{$\operatorname{LSD}^{\mathrm{d}}$} & \multicolumn{2}{|c|}{ Sex } & \multirow[b]{2}{*}{$\mathrm{LSD}^{\mathrm{c}}$} \\
\hline & Positive & Negative & & Ram & Ewe & \\
\hline $\mathrm{Ca}$ & $6.106^{\mathrm{a}}$ & $4.144^{b}$ & 1.678 & 5.207 & 5.148 & $\mathrm{NS}^{\mathrm{d}}$ \\
\hline $\mathrm{Fe}$ & $1.783^{\mathrm{a}}$ & $1.250^{\mathrm{b}}$ & 0.399 & 1.541 & 1.519 & NS \\
\hline $\mathrm{Se}$ & 0.069 & 0.058 & NS & 0.054 & 0.078 & NS \\
\hline $\mathrm{K}$ & 130.9 & 116.7 & NS & 127.5 & 119.5 & NS \\
\hline $\mathrm{Mg}$ & 18.58 & 15.95 & NS & 17.35 & 17.34 & NS \\
\hline $\mathrm{Na}$ & 17.67 & 15.82 & NS & 17.53 & 15.76 & NS \\
\hline $\mathrm{P}$ & $120.2^{\mathrm{a}}$ & $101.8^{\mathrm{b}}$ & 16.97 & 112.4 & 110.3 & NS \\
\hline $\mathrm{Zn}$ & $2.855^{\mathrm{a}}$ & $2.281^{\mathrm{b}}$ & 0.404 & 2.685 & 2.443 & NS \\
\hline $\mathrm{Cu}$ & 0.007 & 0.017 & NS & 0.021 & 0.001 & NS \\
\hline $\mathrm{Pb}$ & 0.004 & $\operatorname{tr}^{\mathrm{e}}$ & NS & 0.002 & 0.002 & NS \\
\hline $\begin{array}{l}{ }^{\mathrm{a}, \mathrm{b}} \text { Meal } \\
{ }^{\mathrm{c}} \text { Least } \\
{ }^{\mathrm{d}} \text { Not si } \\
\mathrm{e}^{\mathrm{e}} \text { trace }\end{array}$ & $\begin{array}{l}\text { e same } \mathrm{r} \\
\text { ant diffe } \\
\mathrm{nt}(\mathrm{P}>0 \\
01 \mathrm{mg} / 1 \mathrm{l}\end{array}$ & $\begin{array}{l}\text { ith differe } \\
(\mathrm{P}=0.0\end{array}$ & & signifi & differe & $\leq 0.05)$ \\
\hline
\end{tabular}

Marked variations in the mineral composition of meat due to the effects of age, feeding regimen (diet), breed, season and geographical differences have been noted. The mineral content of retail cuts within any single carcass also varies significantly (Ono et al,. 1984; Lin et al., 1989). The latter is caused by variation in muscle fibre type and physical activity between muscles (Kotula \& Lusby, 1982). The sheep in the present study were selected from a single geographical location, feeding regimen (diet) and the same age group. It is well known that meat is an excellent food source of $\mathrm{Fe}$ and $\mathrm{Zn}$, especially considering the higher bioavailability of these two minerals compared to that from plants (Lin et al., 1989). Approximately $40 \%$ of the $\mathrm{Fe}$ in meat is heme iron, and this form of Fe is more available to man than non-heme iron (Simonsen et al., 1988). Meat, therefore, contributes significantly to the minerals required in the human diet. The concentration of $\mathrm{Fe}, \mathrm{Zn}$ and $\mathrm{Cu}$ in meat is higher than that provided by the other food sources (non animal) in the rest of the diet as a whole (Williams, 1987). The results from this investigation indicated significant differences in the mineral composition between lines. The meat from the positive line could contribute higher concentrations of minerals to the human diet than the negative line could.

The fatty acid composition of the M. semimembranosus from the four sheep groups is presented in Table 10. Oleic acid (C18:1n-9) occurred at the highest proportion of all fatty acids, contributing to approximately $39 \%$ of the total fatty acid content, followed by palmitic acid (C16:0) $( \pm 27 \%)$ and stearic acid (C18:0) $( \pm 23 \%)$. These results agree with those of Webb et al. (1997) who found that C16:0, C18:0 and C18:1n-9 constituted the highest proportion of the fatty acids in the meat of South African Mutton Merino wethers. No significant differences existed between the four groups in the concentration of the major saturated fatty acids (SFA), i.e. C16:0 and C18:0 (Table 10). However, there were significant differences (P $\leq 0.05)$ between groups in arachidic acid (C20:0) and lignoceric acid (C24:0) concentrations. Total SFA concentrations did not differ significantly between the four groups. Eicosenoic acid (C20:1n-9) was the only mono-unsaturated fatty acid (MUFA) that differed $(\mathrm{P} \leq 0.05)$ between the four groups, with the ewes having a higher proportion than the rams. Total MUFA did not differ $(\mathrm{P}>0.05)$ between groups. As far as the polyunsaturated fatty acids (PUFA) are concerned, differences $(\mathrm{P} \leq 0.05)$ were detected between the groups in linoleic acid (C18:2n-6), homo- $\gamma$-linolenic acid (C20:3n-6), arachidonic acid (C20:4n-6), eicosapentaenoic acid (C20:5n-3), docosadienoic acid (C22:2n-6), docosapentaenoic acid (C22:5n-3) and docosahexaenoic acid (C22:6n-3) concentrations. These differences in individual PUFA resulted in a significant difference (P $\leq 0.05)$ in total PUFA between the four groups. The PR group had the highest total PUFA concentration $( \pm 8 \%)$ and the NR the lowest $( \pm 6 \%)$. 
Table 10 Means proportions of the fatty acid content of M. semimembranosus as influenced by the interaction between the main effects of line and sex $(\%$ by weight of total fatty acids)

\begin{tabular}{|c|c|c|c|c|c|}
\hline \multirow{2}{*}{$\begin{array}{r}\text { Line } \\
\text { Sex } \\
\end{array}$} & \multicolumn{2}{|c|}{ Positive } & \multicolumn{2}{|c|}{ Negative } & \multirow[b]{2}{*}{$\operatorname{LSD}^{\mathrm{d}}$} \\
\hline & Ewe & Ram & Ewe & Ram & \\
\hline C14:0 & 2.988 & 2.342 & 2.383 & 2.412 & $\mathrm{NS}^{\mathrm{e}}$ \\
\hline C16:0 & 26.33 & 27.65 & 27.02 & 27.65 & NS \\
\hline C18:0 & 23.27 & 21.63 & 24.28 & 22.84 & NS \\
\hline C20:0 & $0.317^{\mathrm{a}}$ & $0.202^{b}$ & $0.263^{\mathrm{ab}}$ & $0.303^{\mathrm{a}}$ & 0.068 \\
\hline $\mathrm{C} 22: 0$ & 0.063 & 0.044 & 0.047 & 0.056 & NS \\
\hline $\mathrm{C} 24: 0$ & $0.038^{\mathrm{ab}}$ & $0.050^{\mathrm{a}}$ & $0.040^{\mathrm{ab}}$ & $0.026^{\mathrm{b}}$ & 0.021 \\
\hline $\mathrm{C} 16: 1 n-7$ & 1.423 & 1.590 & 1.197 & 1.542 & NS \\
\hline $\mathrm{C} 18: 1 n-9$ & 38.56 & 38.52 & 38.22 & 39.18 & NS \\
\hline $\mathrm{C} 20: 1 n-9$ & $0.200^{\mathrm{a}}$ & $0.106^{b}$ & $0.247^{\mathrm{a}}$ & $0.098^{b}$ & 0.065 \\
\hline $\mathrm{C} 24: 1 n-9$ & 0.023 & 0.020 & 0.017 & 0.016 & NS \\
\hline C18:2n-6 & $3.735^{\mathrm{ab}}$ & $4.356^{\mathrm{a}}$ & $3.570^{\mathrm{ab}}$ & $3.406^{\mathrm{b}}$ & 0.817 \\
\hline C18:3n-6 & 0.093 & 0.053 & 0.070 & 0.074 & NS \\
\hline C18:3n-3 & 1.310 & 1.260 & 1.277 & 1.140 & NS \\
\hline $\mathrm{C} 20: 2 n-6$ & 0.055 & 0.022 & 0.033 & 0.040 & NS \\
\hline$C 20: 3 n-6$ & $0.098^{\mathrm{b}}$ & $0.138^{\mathrm{a}}$ & $0.087^{\mathrm{b}}$ & $0.076^{\mathrm{b}}$ & 0.030 \\
\hline $\mathrm{C} 20: 4 n-6$ & $0.605^{\mathrm{ab}}$ & $0.848^{\mathrm{a}}$ & $0.470^{\mathrm{b}}$ & $0.472^{b}$ & 0.266 \\
\hline $\mathrm{C} 20: 3 n-3$ & 0.025 & 0.010 & 0.013 & 0.014 & NS \\
\hline $\mathrm{C} 20: 5 n-3$ & $0.298^{\mathrm{ab}}$ & $0.450^{\mathrm{a}}$ & $0.220^{\mathrm{b}}$ & $0.270^{\mathrm{b}}$ & 0.176 \\
\hline$C 22: 2 n-6$ & $0.080^{\mathrm{ab}}$ & $0.074^{\mathrm{b}}$ & $0.220^{\mathrm{a}}$ & $0.036^{\mathrm{b}}$ & 0.141 \\
\hline$C 22: 4 n-6$ & 0.028 & 0.038 & 0.025 & 0.026 & NS \\
\hline $\mathrm{C} 22: 5 n-3$ & $0.398^{\mathrm{ab}}$ & $0.500^{\mathrm{a}}$ & $0.210^{c}$ & $0.284^{\mathrm{bc}}$ & 0.167 \\
\hline$C 22: 6 n-3$ & $0.120^{\mathrm{a}}$ & $0.118^{\mathrm{a}}$ & $0.060^{\mathrm{b}}$ & $0.072^{\mathrm{b}}$ & 0.046 \\
\hline $\mathrm{SFA}^{\mathrm{f}}$ & 52.97 & 51.89 & 54.04 & 53.25 & NS \\
\hline MUFA $^{\mathrm{g}}$ & 40.21 & 40.23 & 39.69 & 40.83 & NS \\
\hline PUFA $^{\mathrm{h}}$ & $6.835^{\mathrm{ab}}$ & $7.924^{\mathrm{a}}$ & $6.293^{\mathrm{ab}}$ & $5.914^{\mathrm{b}}$ & 1.699 \\
\hline PUFA:SFA ${ }^{\mathrm{i}}$ & $0.130^{\mathrm{ab}}$ & $0.154^{\mathrm{a}}$ & $0.120^{\mathrm{ab}}$ & $0.112^{\mathrm{b}}$ & 0.036 \\
\hline DFA $^{\mathrm{j}}$ & 70.31 & 69.78 & 70.27 & 69.59 & NS \\
\hline$(\mathrm{C} 18: 0+\mathrm{C} 18: 1): \mathrm{C} 16: 0$ & 2.370 & 2.202 & 2.313 & 2.266 & NS \\
\hline \multicolumn{6}{|c|}{ a,b,c Means in the same row with different superscripts differ significantly $(\mathrm{P} \leq 0.05)$} \\
\hline \multicolumn{6}{|c|}{${ }^{\mathrm{d}}$ Least significant difference $(\mathrm{P}=0.05)$} \\
\hline \multicolumn{6}{|c|}{${ }^{\mathrm{e}}$ Not significant $(\mathrm{P}>0.05)$} \\
\hline \multicolumn{6}{|c|}{${ }^{\mathrm{f}}$ Saturated fatty acids } \\
\hline \multicolumn{6}{|c|}{${ }^{g}$ Mono-unsaturated fatty acids } \\
\hline \multicolumn{6}{|c|}{${ }^{\mathrm{h}}$ Polyunsaturated fatty acids } \\
\hline${ }^{\mathrm{i}}$ Ratio of polyunsaturate & o satur & acids & & & \\
\hline${ }^{\mathrm{j}}$ Desirable fatty acids & & & & & \\
\hline
\end{tabular}

When pooled across selection lines, no concentration differences $(\mathrm{P}>0.05)$ occurred between sexes for total SFA, total MUFA or total PUFA (Table 11). Except for C20:1n-9, no differences (P > 0.05) were detected in the individual fatty acid composition. The absence of significant differences in SFA, MUFA and PUFA concentrations between males and females suggests that the fatty acid profile was independent of sex (at a slaughter weight of $c a .43 \mathrm{~kg}$ ). These results agree with the findings of Horcoda et al. (1998), but differ from those of Solomon et al. (1990), who found that the ram lambs had lipids richer in PUFA and poorer in SFA than ewes. The latter could be due to an age effect as the sheep used in the present investigation were older.

When pooled across sexes (Table 11), the positive line animals had a higher PUFA concentration ( $c a$. $7 \%$ ) than their $\mathrm{N}$ group contemporaries $(c a .6 \%)$. The total SFA and MUFA composition did not differ $(\mathrm{P}>$ $0.05)$ between the lines. The higher $(\mathrm{P} \leq 0.05)$ proportions of the $\mathrm{C} 18: 2 n-6, \mathrm{C} 20: 3 n-6, \mathrm{C} 20: 4 n-6, \mathrm{C} 20: 5 n-3$, $\mathrm{C} 22: 5 n-3$ and $\mathrm{C} 22: 6 n-3$ PUFAs in the $\mathrm{P}$ group resulted in this group having a higher $(\mathrm{P} \leq 0.05)$ total PUFA concentration than the $\mathrm{N}$ group. 
Table 11 Means proportions of the fatty acid content of $M$. semimembranosus as affected by the main effects of line and sex ( $\%$ by weight of total fatty acids)

\begin{tabular}{|c|c|c|c|c|c|c|}
\hline & \multicolumn{2}{|c|}{ Line } & \multirow[b]{2}{*}{$\mathrm{LSD}^{\mathrm{d}}$} & \multicolumn{2}{|c|}{ Sex } & \multirow[b]{2}{*}{ LSD } \\
\hline & Positive & Negative & & Ram & Ewe & \\
\hline C14:0 & 2.629 & 2.401 & $\mathrm{NS}^{\mathrm{e}}$ & 2.377 & 2.729 & NS \\
\hline C16:0 & 27.06 & 27.41 & NS & 27.65 & 26.63 & NS \\
\hline C18:0 & 23.38 & 22.36 & NS & 22.23 & 23.61 & NS \\
\hline C20:0 & 0.245 & 0.286 & NS & 0.247 & 0.290 & NS \\
\hline $\mathrm{C} 22: 0$ & 0.052 & 0.053 & NS & 0.050 & 0.055 & NS \\
\hline $\mathrm{C} 24: 0$ & 0.043 & 0.031 & NS & 0.035 & 0.039 & NS \\
\hline $\mathrm{C} 16: 1 n-7$ & 1.516 & 1.413 & NS & 1.566 & 1.326 & NS \\
\hline $\mathrm{C} 18: 1 n-9$ & 38.54 & 38.82 & NS & 38.85 & 38.42 & NS \\
\hline $\mathrm{C} 20: 1 n-9$ & 0.148 & 0.154 & NS & $0.102^{\mathrm{b}}$ & $0.220^{\mathrm{a}}$ & 0.046 \\
\hline $\mathrm{C} 24: 1 n-9$ & 0.021 & 0.016 & NS & 0.018 & 0.020 & NS \\
\hline C18:2n-6 & $4.080^{\mathrm{a}}$ & $3.468^{\mathrm{b}}$ & 0.566 & 3.881 & 3.664 & NS \\
\hline C18:3n-6 & 0.073 & 0.073 & NS & 0.064 & 0.083 & NS \\
\hline $\mathrm{C} 18: 3 n-3$ & 1.282 & 1.191 & NS & 1.200 & 1.296 & NS \\
\hline C20:2n-6 & 0.037 & 0.038 & NS & 0.031 & 0.046 & NS \\
\hline C20:3n-6 & $0.120^{\mathrm{a}}$ & $0.080^{\mathrm{b}}$ & 0.021 & 0.107 & 0.093 & NS \\
\hline C20:4n-6 & $0.740^{\mathrm{a}}$ & $0.471^{\mathrm{b}}$ & 0.184 & 0.660 & 0.547 & NS \\
\hline $\mathrm{C} 20: 3 n-3$ & 0.017 & 0.014 & NS & 0.012 & 0.020 & NS \\
\hline $\mathrm{C} 20: 5 n-3$ & $0.382^{\mathrm{a}}$ & $0.251^{\mathrm{b}}$ & 0.122 & 0.360 & 0.264 & NS \\
\hline $\mathrm{C} 22: 2 n-6$ & 0.077 & 0.105 & NS & 0.055 & 0.140 & NS \\
\hline $\mathrm{C} 22: 4 n 6$ & 0.033 & 0.026 & NS & 0.031 & 0.027 & NS \\
\hline $\mathrm{C} 22: 5 n 3$ & $0.454^{\mathrm{a}}$ & $0.256^{\mathrm{b}}$ & 0.115 & 0.392 & 0.317 & NS \\
\hline $\mathrm{C} 22: 6 n 3$ & $0.119^{\mathrm{a}}$ & $0.068^{\mathrm{b}}$ & 0.032 & 0.095 & 0.094 & NS \\
\hline $\mathrm{SFA}^{\mathrm{f}}$ & 52.37 & 53.55 & NS & 52.57 & 53.42 & NS \\
\hline MUFA $^{\mathrm{g}}$ & 40.22 & 40.40 & NS & 40.53 & 39.98 & NS \\
\hline PUFA $^{\mathrm{h}}$ & $7.440^{\mathrm{a}}$ & $6.056^{\mathrm{b}}$ & 1.177 & 6.919 & 6.603 & NS \\
\hline PUFA:SFA ${ }^{\mathrm{i}}$ & $0.143^{\mathrm{a}}$ & $0.115^{\mathrm{b}}$ & 0.025 & 0.133 & 0.126 & NS \\
\hline $\mathrm{DFA}^{\mathrm{j}}$ & 70.13 & 69.84 & NS & 69.68 & 70.29 & NS \\
\hline$(\mathrm{C} 18: 0+\mathrm{C} 18: 1): \mathrm{C} 16: 0$ & 2.277 & 2.284 & NS & 2.234 & 2.346 & NS \\
\hline \multicolumn{7}{|c|}{ a,b Means in the same row with different superscripts differ $(\mathrm{P} \leq 0.05)$} \\
\hline \multicolumn{7}{|c|}{${ }^{\mathrm{d}}$ Least significant difference $(\mathrm{P}=0.05)$} \\
\hline \multicolumn{7}{|c|}{${ }^{\mathrm{e}} \mathrm{NS}=$ Not significant $(\mathrm{P}>0.05)$} \\
\hline \multicolumn{7}{|c|}{${ }^{\mathrm{f}}$ Saturated fatty acids } \\
\hline \multicolumn{7}{|c|}{${ }^{\mathrm{g}}$ Mono-unsaturated fatty acids } \\
\hline \multicolumn{7}{|c|}{${ }^{\mathrm{h}}$ Polyunsaturated fatty acids } \\
\hline \multicolumn{7}{|c|}{${ }^{\mathrm{i}}$ Ratio of polyunsaturated to saturated fatty acids } \\
\hline${ }^{\mathrm{j}}$ Desirable fatty acids & & & & & & \\
\hline
\end{tabular}

Desirable fatty acids (DFA), according to the health classification of Rhee (1992), are the sum of all unsaturated fatty acids and stearic acid. Oleic acid (C18:1n-9), Palmitic acid (C16:0) and stearic acid (C18:0) represented the majority of the fatty acids measured in the M. semimembranosus in this investigation. It is well known that C16:0 increases blood cholesterol levels, whereas C18:0 has no effect and C18:1n-9 decreases blood cholesterol content. Therefore, the ratio of $(\mathrm{C} 18: 0+\mathrm{C} 18: 1): \mathrm{C} 16: 0$ indicates the possible health effects of the lipids (Grundy, 1997; Banskalievaa et al., 2000). Within the four reproduction fitness groups (Table 10), as well as in the pooled groups for sexes and lines (Table 11), no significant differences were detected in DFA or $(\mathrm{C} 18: 0+\mathrm{C} 18: 1): \mathrm{C} 16$.

The PUFA:SFA ratio is an important guideline illustrating the total impact of SFA on blood cholesterol. Values of 0.45 or above for the PUFA:SFA ratio in dietary fats have been recommended in the United Kingdom (Warris, 2000). The PUFA:SFA ratio is lower in ruminant than non-ruminant meat because of the bio-hydrogenation of dietary unsaturated fatty acids by ruminal micro-organisms (Banskalievaa et al., 2000). Particularly the concentration of linoleic acid (C18:2n-6), the major plant fatty acid, is therefore much lower in ruminant than in non-ruminant tissue. These factors lead to ruminant meat having a PUFA:SFA ratio below the value of 0.45 required in the human diet (Warris, 2000). Previous reports found PUFA:SFA 
ratio of lipids from bovine or lamb meat to be between 0.11 and 0.15 (Geay et al.,2001). The PUFA:SFA ratio of the four groups in this investigation differed $(\mathrm{P} \leq 0.05)$, but were all markedly below the recommended value of 0.45 . The $\mathrm{P}$ group had a higher PUFA:SFA ratio of 0.143 , compared to the $\mathrm{N}$ production group that had a PUFA:SFA ratio of 0.115 .

\section{Conclusions}

The objective of this investigation was to determine if meat quality differed between two lines of South African Merino sheep that were divergently selected for and against multiple-rearing ability. Differences detected in meat quality between the two lines were of a slight magnitude, although more important differences were found in the WBS values and mineral and fatty acid composition of the meat. However, the latter did not affect the sensory quality of the meat. This investigation provides important scientific insight into the effect of reproduction rate on general mutton quality. Results indicated that the selection of sheep for an increased multiple-rearing ability did not result in negative correlated responses on general mutton quality and therefore appears to be feasible. The only exception was with regard to tenderness, where the mutton derived from the positive line animals was generally tougher, according to WBS measurements, than the negative line contemporaries. This point needs further elucidation, as this is a quality attribute that plays an important role in a consumer's decision on whether to purchase or not to purchase a specific meat type.

Analytical results of the fatty acid and mineral content of mutton derived from sheep raised under typical South African conditions are reported on a fresh meat basis and will serve as valuable information to use in national food composition tables.

\section{Acknowledgement}

The financial contributions of the South African wool industry to the maintenance of the breeding flock, the Technology and Human Resources for Industry Program (THRIP) and the National Resources Foundation (NRF) of South Africa are gratefully acknowledged.

\section{References}

Alexander, G., 1988. What makes a good mother? Proc. Austr. Soc. Anim. Prod. 17, 25-41.

AMSA, 1978. Guidelines for cookery and sensory evaluation of meat. American Meat Science Association, National Livestock and Meat board, Chicago, IL.

AOAC, 1997. Official Methods of Analysis. (16 $6^{\text {th }}$ ed.). Association of Official Analytical Chemists, Inc., Arlington, Virginia, USA.

Banskalievaa, V., Sahlu, T. \& Goetsch, A. L., 2000. Fatty acid composition of goat muscles and fat deposits: a review. Small Rum. Res. 37, 255-268.

Cloete, S.W.P., 1999. Selection for weight of lamb weaned per breeding ewe. Elsenburg J. 1/2, 13-16.

Cloete, S.W.P. \& Durand, A., 1994. A preliminary note on Merino sheep subjected to divergent selection on maternal values for lambs weaned per ewe joined. S. Afr. J. Anim. Sci. 24, 27-29.

Cloete, S.W.P. \& Olivier, J.J., 1998. Direct correlated responses to divergent selection for multiple-rearing ability on South African Merinos. In: Proc. $36^{\text {th }}$ National Congr. S. Afr. Soc. Anim. Sci., University of Stellenbosch and Elsenburg, 5-8 April 1998, pp. 65-68.

Cloete, S.W.P. \& Scholtz, A.J., 1998. Lamb survival in relation to lambing and neonatal behaviour in medium wool Merino lines divergently selected for multiple-rearing ability. Aust. J. Exp. Agric. 38, 801-811.

Crouse, J.D., Ferrel, C.L. \& Cross, H.R., 1983. The effect of dietary ingredients, sex, and slaughter weight on cooked meat flavour profiles of market lamb. J. Anim. Sci. 57, 1146-1153.

Ellis, M., Webster, G.M., Merrell, B.G. \& Brown, I., 1997. The influence of terminal sire breed on carcass composition and eating quality of crossbred lambs. Anim. Sci. 64, 77-86.

Fisher, A.V., Enser, M., Richardson, R.I., Wood, J.D., Nute, G.R., Kurt, E., Sinclair, L.A. \& Wilkonson, R.G., 1999. Fatty acid composition and eating quality of lamb types derived from four diverse breed $\mathrm{x}$ production systems. Meat Sci. 55, 141-147.

Geay, Y., Boauchart, D., Hocquette J. \& Culiole, J., 2001. Effect of nutritional factors on biochemical, structural and metabolic characteristics of muscles in ruminants, consequences on dietic value and sensorial qualities of meat. Ruminant Nutr. \& Meat Quality, 41, 1-26. 
Glass, G.V., Peckham, P.D. \& Sanders, J.R., 1972. Consequences of failure to meet assumptions underlying the fixed effects analyses of variance and covariance. Rev. Educ. Res. 42, 237-288.

Grundy, S.M., 1997. What is the desirable ratio of saturated, polyunsaturated and monounsaturated fatty acid in the diet? Amer. J. Clin. Nutr. 66, S988-S990.

Honikel, K.O., 1998. Reference methods for the assessment of physical characteristics of meat. Meat Sci., 49, 447-457.

Horcada, A., Beriain M.J., Pyrroyo, G., Lizaso, G. \& Chasco, J., 1998. Effect of sex on meat quality of Spanish lamb breeds (Lacha and Rasa Aragonesa). Anim. Sci. 67, 541-547.

Jeremiah, L.E., Jones, S.D.M., Tong, A.K.W., Robertson, W.M. \& Gibson, L.L., 1997. The influence of lamb chronical age, slaughter weight and gender on carcass composition. Sheep \& Goat Res. J. 13, 30-38.

Jeremiah, L.E., Tong, A.K.W. \& Gibson, L.L., 1998. The influence of lamb chronical age, slaughter weight, and gender on cooking properties and palatability. Sheep \& Goat Res. J. 14, 156-166.

Kemp, J.D., Johnson, A.E., Steward, D.F., Ely, D.G. \& Fox, J.D., 1976. Effect of dietary protein, slaughter weight, and sex on carcass composition, organoleptic properties, and cooking losses of lamb. J. Anim. Sci. 42, 575-583.

Kotula, A.W. \& Lusby, W.R., 1982. Mineral composition of muscles of 1-6 year old steers. J. Anim. Sci. 54, 544-548.

Laas, T.M., 1995. Breeding for quality and profit. Proc. Austr. Assoc. Anim. Breeding \& Genetics, 11, 2233.

Lee, C.M., Trevino, B. \& Chaiyawat, M., 1996. A simple and rapid solvent extraction method for determining total lipids in fish tissue. J. AOAC Int. 79, 487-492.

Lin, K.C. Cross, H.R., Johnson, H.K., Bernstein, B.C., Randecker, V. \& Field, R.A., 1989. Mineral composition of lamb carcasses from the United States and New Zealand. Meat Sci. 24, 47-59.

Morrison, W.R. \& Smith, M.L., 1964. Preparation of fatty acid methyl esters and dimethylacetals from lipids with boron fluoride-methanol. J. Lipid Res. 5, 600-602.

Olivier, J.J., 1999. The South African Merino performance testing scheme. Premium Quality Wool Symposium. In: Proc. Assoc. Advancement of Animal Breeding \& Genetics 13, 119-124.

Ono, K., Berry, B.W., Johnson, E., Russek, E., Parker, C.F., Cahill, V.R. \& Althouse, P.G., 1984. Nutrient composition of Lamb of Two Age Groups. J. Food Sci. 49, 1233-1239.

Pinta, M., 1982. Modern methods for trace element analysis. (3rd ed.). Butterworths Ltd., Borough Green, Sevenoaks.

Rhee, K.S., 1992. Fatty acids in meat and meat products. In: Fatty acids in foods and their health implications. Eds. Chow, C.K., Marcel Dekker Inc., New York.

Safari, E., Forgarty, N.M., Ferrier, G.R., Hopkins, L.D. \& Gilmour, A., 2001. Diverse lamb genotypes. 3. Eating quality and the relationship between its objective measurement and sensory assessment. Meat Sci. 57, 153-159.

SAS, 1990. Statistical Analysis Systems user's guide (4th ed.). SAS Institute Inc., Cary, NC.

Shapiro, S.S. \& Wilk, M.B., 1965. An analysis of variance test for normality (complete samples). Biometrika 52, 591-611.

Simonsen, B., Hamm, R. \& Rogowski, B., 1988. Meat as Food. In: World Animal Science, Meat Science, Milk Science and Technology. Eds. Cross, H.R. \& Overby, A.J., Elsevier Science Publishers B.V., New York. pp. 141-165.

Solomon, M.B., Lynch, G.P., Ono, K. \& Paroczay, E., 1990. Lipid composition of muscle and adipose tissue from crossbred ram, wether and cryptorchid lambs. J. Anim. Sci. 68, 137-142.

Viljoen, D.L., Muller, M., De Swart, J.B., Sadie, A. \& Vosloo, M.C., 2001. Computerized electronic temperature control system for thermal efficiency during baking in food research. Int. J. Cons. Studies $25,30-42$.

Voisey, P.W., 1976. Engineering assessment and critique of instruments used for meat tenderness evaluation. J. Text. Stud. 7, 11-48.

Warris, P.D., 2000. Meat science: An introductory text. CABI Publishing, New York.

Webb, E.C., Bosman, M.J.C. \& Casey, N.H., 1994. Dietary influences on subcutaneous fatty acid profiles and sensory characteristics of Dorper and SA Mutton Merino wethers. S. Afr. J. Food Sci. Nutr. 6, 4550 . 
Webb, E.C., Bosman, M.J.C. \& Casey, N.H., 1997. Influence of dietary presentation on the composition of fatty acids and sensory characteristics of meat derived from wethers. S. Afr. J. Food Sci. Nutr. 9, 6976.

Williams, J.C., 1987. Contribution of red meat to the U.S. diet. Food and Nutrition News 59, 37-40.

Young, O.A., Reid, D.H. \& Scales, G.H., 1993. Effect of breed and ultimate $\mathrm{pH}$ on the odour and flavour of sheep meat. N. Z. J. Agric. Res. 36, 363-370. 